\title{
The Relationship Between Social Comparison and Self- Esteem Among Late Adolescent Instagram Users
}

\author{
Alodia Alodia ${ }^{1}$ Denrich Suryadi ${ }^{*}$ \\ ${ }^{1}$ Faculty of Psychology, Universitas Tarumanagara, West Jakarta, Indonesia \\ *Corresponding author. Email: denrichs@fpsi.untar.ac.id
}

\begin{abstract}
Instagram is a social media that is popular among all age groups, but especially late teens. Social media allows each individual to explore, see, imitate, and even define a standard. When teenagers compare themselves to other people on Instagram, this certainly has an impact on their self-esteem. The aim of this study is to determine the relationship between social comparison among late adolescents who use Instagram and their self-esteem. This research uses quantitative research method. The data used in this study is primary data collected from 198 respondents in West Jakarta with an age range of 18-22 years, who use Instagram for at least 3 hours. Participants in this study were selected by purposive sampling, and the data were processed using correlation testing. The result is $r=-0.245, p>0.01$. Based on the results of the correlation test, it can be concluded that there is a correlation between social comparison and self-esteem.
\end{abstract}

\section{Keywords: social comparison, self-esteem, Instagram, late adolescence}

\section{INTRODUCTION}

Social media is currently the most popular media platform. Instagram is a social media that is loved today among late teens. According to Napoleon (2020) [1], the highest number of Instagram users is late adolescents aged 18-24 years, as much as 36.3 percent. Social media plays an important role in shaping the identity of today's teenagers. Teens form profiles on Instagram and share photos, videos, or stories that they think are their own world, much like personal fairy tales (J. W. Santrock, 2014) [2]. Instagram allows users to beautify their photos by applying various enhancement filters (Jiang \& Ngien, 2020) [3].

Erikson explained that in early adolescence, identity vs identity confusion occurs, where individuals seek and build new identities [4]. This stage must be passed so that there is no uncertainty and discomfort about the role and future of late adolescence. Santrock (2005) stated [5] that exploration carried out by adolescents in search of their identity continues until late adolescence, they try hard to be accepted and appreciated by their environment. WHO (2010) also argued [6] that late adolescents have started thinking maturely and socialize less, due to being more focused on committed relationships (engaged or married). Social media helps late teens to build, find, define, and stay in touch with the outside world.

Self-esteem is formed since childhood, but significant changes occur during early adolescence to the end. This is because teenagers begin to explore themselves in search of self-identity and usually, this exploration occurs in late adolescence (Santrock, 2005) [5]. Globally, self-esteem is defined as a person's positive or negative evaluation of himself as a whole (Rosenberg et al., 1995) [7]. Instagram is a medium where teenagers explore plenty of information, often comparing the information they see with themselves. This is called social comparison. Myers (2016) [8] stated that social comparison is evaluating a person's opinion and abilities by comparing oneself with others. Festinger \& Richins (in Schwartz et al., 2011) [9] claimed that the essence of social comparison theory is that people have a need to evaluate or compare themselves, are influenced by the ideal media picture, implicitly and explicitly. This is what influences individuals to compare themselves with other people or existing information, resulting in decreased self-esteem or self-confidence.

\subsection{Writing Structure}

Systematically, this study was written into five chapters. The first part contains a description of the discussion on the background of the problem, problem formulation, research objectives, the benefits of the study both theoretically and practically, and systematics of writing. The second part contains a description of the theory which forms the basis of the theory in this study and the framework. Meanwhile, the theory used was the theory of attachment theory, the theory of social comparison, and the theory of self-esteem. The third section contains a part of the research methodology which contains criteria and descriptions of participants, types of research, research settings and tools, research measurement tools, research preparation, and implementation, as well as data processing and analysis techniques. The fourth section contains an overview of the research variables, the main data analysis which includes hypothesis testing, and additional data analysis. The fifth 
part is the closing which contains conclusions, discussions, and theoretical and practical suggestions.

\section{LITERATURE REVIEW}

\subsection{Instagram}

Instagram is a photo sharing website which is very popular among teenagers and young adults and has about 85 million users (Golbeck, 2015) [01]. Instagram is a social media platform that primarily focuses on images and short captions. It is the number one photo sharing platform (Chua \& Chang, 2016) [11]. Betari (in Amelia, 2019) listed the basic features of Instagram, which are (1) Taking photos and videos, (2) Likes and Comments, (3) Direct messages, (4) Explore, (5) Instagram stories [12].

\subsection{Late Adolescence}

Adolescence is a developmental transition period which involves physical, cognitive, emotional, and social changes in various ways according to social, cultural, and economic situations (Papalia et.al., 2014) [13]. According to Erikson (in Corey, 2017) [14] in early adolescence identity vs identity confusion takes place (12 years to 18 years). This is the transition between childhood and adulthood, the time to test boundaries, to break dependency ties, and to build new identities. The main conflict centers on clarifying selfidentity, purpose in life, and meaning of life. Failure to achieve identity leads to identity confusion. According to Santrock (2005), adolescence is a period of transitional development between childhood and adulthood which includes biological, cognitive, and socio-emotional changes. Adolescence usually starts in the 10-13 year age group and ends in the 18-22 year age group [5].

Philip Meilman (1979), conducted an identity status study to observe obvious developments. The results showed that, at age 21 or older, most of the participants achieved stability [15]. This assumes that the settlement of the identity crisis occurs much later than Erikson assumed. Erikson (1987) argued that, that late adolescence is faced with adult tasks, related to what is seen in others and compared to what they feel.

\subsection{Social Comparison}

Social comparison is comparing oneself with other similar people and avoiding false role models that cannot be reached in their online network (Noon, 2020) [16]. Festinger et al. (in Noon, 2020) divides social comparisons into two main forms: (a) Social comparisons of ability, namely comparisons of achievement and performance when individuals try to determine how well they are doing relative to others, to judge and compete with. (b) Social comparisons of opinion is when individuals take advantage of the opinions of others to evaluate whether their own beliefs and preferences are accurate or socially acceptable, and thus, other people are viewed not as competitors, but as role models, consultants, and informants.

\subsection{Self-Esteem}

Rosenberg (1965) defined self-esteem as a positive or negative evaluation of oneself [17]. Overall, it is called global self-esteem, which is a person's positive or negative evaluation of himself as a whole (Rosenberg et al., 1995) [7]. Branden (in Murk, 1995) divided self-esteem into two: (1) To consider the individual self-effective, to believe in one's ability to think, learn, choose and make correct decisions, and, by extension, to overcome challenges and produce change. (2) To respect oneself, belief in one's right to be happy and, by extension, the belief that people deserve the respect, love and self-fulfilment in their lives [18].

\section{RESEARCH METHOD}

The sampling technique used in this study was purposive sampling, and the method of this study is non-experimental quantitative correlational method. Based on data obtained from 198 participants, it is known that participants have an age range between 18-22 years, consisting of 101 male participants and 97 female participants. The independent variable in this study is Social Comparison, using an instrument by Noon (2020) which has been adjusted for Instagram users. This instrument consists of 2 dimensions, divided into 4 opinion items and 4 ability items, with a total of 8 questions.

Table 1. Social Comparison Reliability

\begin{tabular}{lcc}
\multirow{2}{*}{ Dimension } & \multicolumn{2}{c}{ A Cronbach } \\
\cline { 2 - 3 } & $\begin{array}{c}\text { Before } \\
\text { Reliability Test }\end{array}$ & $\begin{array}{c}\text { After Reliability } \\
\text { Test }\end{array}$ \\
\hline Opinion & 0.736 & 0.736 \\
\hline Ability & 0.819 & 0.819 \\
\hline
\end{tabular}

The measuring instrument for self-esteem variable is provided by the Research and Measurement Department of the Faculty of Psychology, Universitas Tarumanagara (2015) [23] which was adapted from the Rosenberg Selfesteem Scale (RSES) measurement tool. This instrument consists of 2 dimensions, divided into 14 self-acceptance items and 6 self-respect items, with a total of 20 questions.

Table 2. Self-Esteem Reliability

\begin{tabular}{ccc}
\hline \multirow{2}{*}{ Dimension } & \multicolumn{2}{c}{ A Cronbach } \\
\cline { 2 - 3 } & $\begin{array}{c}\text { Before } \\
\text { Reliability Test }\end{array}$ & $\begin{array}{c}\text { After Reliability } \\
\text { Test }\end{array}$ \\
\hline Self-Acceptance & 0.899 & 0.899 \\
\hline
\end{tabular}


Self-Respect

0.823

0.823

\section{DATA ANALYSIS}

Researchers conducted a normality test using the onesample Kolmogorov-Smirnov test. Based on the results of the normality test, the social comparison variable has a pvalue $<0.05$ and the self-esteem variable has a $\mathrm{p}$-value $<$ 0.05 . Based on these two values, it can be concluded that the social comparison and self-esteem variables are not normal.

Table 3. Social Comparison and Self-Esteem Normality Test

\begin{tabular}{lccc}
\hline Variable & Mean & $\begin{array}{c}\text { Asymp. Sig. } \\
\text { (2-tailed) }\end{array}$ & Distribution \\
\hline $\begin{array}{l}\text { Social } \\
\text { Comparison }\end{array}$ & 3.3049 & 0.000 & Not normal \\
Self-esteem & 3.7081 & 0.017 & Not normal
\end{tabular}

Correlation testing was conducted to find out whether there is a relationship between social comparison and selfesteem. Spearman correlation was chosen because the data from the two variables are not normal. The result obtained was $r=-0.245, p>0.01$. Based on the results of the correlation test, it can be concluded that there is a negative but weak correlation between social comparison and selfesteem. The researchers performed additional data analysis, that is comparing social comparison and self-esteem between age groups using One-Way ANOVA. The results for social comparison were $\mathrm{F}=0.513, \mathrm{p}>0.05$.

Table 4. Test of Difference of Social Comparison Among Age

\begin{tabular}{|c|c|c|c|c|}
\hline Age & Mean & \multicolumn{3}{|c|}{ Std. Deviation } \\
\hline 18 & 25.6111 & \multicolumn{3}{|c|}{4.17470} \\
\hline 19 & 29.1111 & \multicolumn{3}{|c|}{2.71314} \\
\hline 20 & 26.7632 & \multicolumn{3}{|c|}{5.07476} \\
\hline 21 & 25.9663 & \multicolumn{3}{|c|}{6.47276} \\
\hline 22 & 26.9091 & \multicolumn{3}{|c|}{5.85411} \\
\hline & $\begin{array}{l}\text { Sum of } \\
\text { Squares }\end{array}$ & $\begin{array}{l}\text { Mean } \\
\text { Square }\end{array}$ & $\mathrm{F}$ & Sig. \\
\hline $\begin{array}{c}\text { Between } \\
\text { Groups }\end{array}$ & 110.202 & 27.551 & .822 & .513 \\
\hline $\begin{array}{l}\text { Within } \\
\text { Groups }\end{array}$ & 6468.570 & 33.516 & & \\
\hline
\end{tabular}

Table 5. Test of Difference of Self-Esteem Among Age

\begin{tabular}{|c|c|c|c|c|}
\hline Age & Mean & \multicolumn{3}{|c|}{ Std. Deviation } \\
\hline 18 & 72.7222 & \multicolumn{3}{|c|}{14.03695} \\
\hline 19 & 73.2222 & \multicolumn{3}{|c|}{8.37821} \\
\hline 20 & 70.3421 & \multicolumn{3}{|c|}{16.17184} \\
\hline 21 & 72.1011 & \multicolumn{3}{|c|}{13.91128} \\
\hline 22 & 76.4773 & \multicolumn{3}{|c|}{14.74353} \\
\hline & $\begin{array}{l}\text { Sum of } \\
\text { Squares }\end{array}$ & $\begin{array}{l}\text { Mean } \\
\text { Square }\end{array}$ & $\mathrm{F}$ & Sig. \\
\hline $\begin{array}{l}\text { Between } \\
\text { Groups }\end{array}$ & 869.360 & 217.340 & 1.050 & .383 \\
\hline $\begin{array}{l}\text { Within } \\
\text { Groups }\end{array}$ & 39964.786 & 207.071 & & \\
\hline
\end{tabular}

Based on these results, it can be concluded that there is no significant difference in social comparison based on age. The self-esteem comparison test obtained $F=0.383$, p > 0.05 . Based on these results, it can be concluded that there is also no significant difference in self-esteem. For social comparison, the results obtained were $t=0.113, p>0.05$.

Table 6. Test of Difference of Social Comparison Among Gender

\begin{tabular}{|c|c|c|c|c|c|}
\hline \multicolumn{2}{|l|}{ Gender } & \multicolumn{2}{|c|}{ Mean } & \multicolumn{2}{|c|}{ Std. Deviation } \\
\hline Male & & & 8020 & 5.99 & 570 \\
\hline \multicolumn{2}{|l|}{ Female } & \multicolumn{2}{|c|}{27.1031} & \multicolumn{2}{|c|}{5.49523} \\
\hline & $\mathrm{F}$ & Sig. & $\mathrm{t}$ & df & $\begin{array}{l}\text { Sig. }(2 \\
\text { tailed) }\end{array}$ \\
\hline $\begin{array}{c}\text { Equal } \\
\text { variances } \\
\text { assumed }\end{array}$ & .180 & .672 & -1.590 & 196 & .113 \\
\hline $\begin{array}{c}\text { Equal } \\
\text { variances not } \\
\text { assumed }\end{array}$ & & & -1.593 & 195.575 & .113 \\
\hline
\end{tabular}

Table 7. Test of Difference of Self-Esteem Among Gender

\begin{tabular}{ccc}
\hline Gender & Mean & Std. Deviation \\
\hline Male & 72.4851 & 15.52070 \\
\hline
\end{tabular}




\begin{tabular}{cccccc}
\hline Female & & 73.2165 & \multicolumn{2}{c}{13.19661} \\
\hline & $\mathrm{F}$ & Sig. & $\mathrm{t}$ & $\mathrm{df}$ & $\begin{array}{c}\text { Sig. (2- } \\
\text { tailed) }\end{array}$ \\
\hline $\begin{array}{c}\text { Equal } \\
\text { variances } \\
\text { assumed }\end{array}$ & 3.016 & .084 & -.357 & 196 & .722 \\
$\begin{array}{c}\text { Equal } \\
\text { variances not } \\
\text { assumed }\end{array}$ & & & -.358 & 193.186 & .721 \\
\hline
\end{tabular}

Based on these results, it can be concluded that the social comparison of female participants is slightly higher than that of male participants, however there is no significant difference in the social comparison in terms of gender. Meanwhile, the results obtained for self-esteem is $\mathrm{t}=0.722$, p> 0.05. Based on these results, it can be concluded that there is also no significant difference in self-esteem in terms of gender. Then, the difference between social comparison and self-esteem in terms of duration of daily use of Instagram was tested using One-Way ANOVA.

Table 8. Test of Difference of Social Comparison Among Duration

\begin{tabular}{|c|c|c|c|c|c|}
\hline \multicolumn{2}{|c|}{ Duration } & Mean & \multicolumn{3}{|c|}{ Std. Deviation } \\
\hline \multicolumn{2}{|c|}{3 hours } & \multicolumn{2}{|l|}{24.6122} & \multicolumn{2}{|c|}{5.89780} \\
\hline \multicolumn{2}{|c|}{$3-4$ hours } & \multicolumn{2}{|l|}{26.0494} & \multicolumn{2}{|c|}{5.80065} \\
\hline \multicolumn{2}{|c|}{$4-5$ hours } & \multicolumn{2}{|l|}{28.2708} & \multicolumn{2}{|c|}{5.72690} \\
\hline \multicolumn{2}{|c|}{$5-6$ hours } & \multicolumn{2}{|l|}{28.4615} & \multicolumn{2}{|c|}{4.19554} \\
\hline \multicolumn{2}{|c|}{$>6$ hours } & \multicolumn{2}{|l|}{27.4286} & \multicolumn{2}{|c|}{3.35942} \\
\hline & $\begin{array}{l}\text { Sum of } \\
\text { Squares }\end{array}$ & df & $\begin{array}{l}\text { Mean } \\
\text { Square }\end{array}$ & $\mathrm{F}$ & Sig. \\
\hline $\begin{array}{c}\text { Between } \\
\text { Groups }\end{array}$ & 396.913 & 4 & 99.228 & 3.098 & .017 \\
\hline $\begin{array}{l}\text { Within } \\
\text { Groups }\end{array}$ & 6181.859 & 193 & 32.030 & & \\
\hline
\end{tabular}

Table 9. Test of Difference of Self-Esteem Among Duration

\begin{tabular}{ccc}
\hline Duration & Mean & Std. Deviation \\
\hline 3 hours & 74.5102 & 14.36884 \\
\hline 3 - 4 hours & 73.4815 & 12.87450 \\
\hline 4 - 5 hours & 70.5833 & 15.29961 \\
\hline
\end{tabular}

\begin{tabular}{|c|c|c|c|c|c|}
\hline \multicolumn{2}{|c|}{$5-6$ hours } & \multicolumn{2}{|l|}{75.5385} & \multicolumn{2}{|c|}{17.10563} \\
\hline \multicolumn{2}{|c|}{$>6$ hours } & \multicolumn{2}{|l|}{64.2857} & \multicolumn{2}{|c|}{18.83892} \\
\hline & $\begin{array}{l}\text { Sum of } \\
\text { Squares }\end{array}$ & $\mathrm{df}$ & $\begin{array}{l}\text { Mean } \\
\text { Square }\end{array}$ & $\mathrm{F}$ & Sig. \\
\hline $\begin{array}{l}\text { Between } \\
\text { Groups }\end{array}$ & 1021.353 & 4 & 255.338 & 1.238 & .296 \\
\hline $\begin{array}{l}\text { Within } \\
\text { Groups }\end{array}$ & 39812.793 & 193 & 206.284 & & \\
\hline
\end{tabular}

There is a significant difference in social comparison in terms of the duration of daily use of Instagram with $\mathrm{F}=$ $0.017, p<0.05$. There is no significant difference in selfesteem in terms of the duration of daily use of Instagram, with $F=0.296, p>0.05$. This study was conducted to examine the relationship between social comparisons and self-esteem in older adolescents who were users of Instagram. From the data analysis, the relationship between social comparisons and self-esteem was found. The results of this study were under the proposed hypothesis. The findings also support several previous studies and literature regarding the use of Instagram which affects social comparison and self-esteem of older adolescents (Jiang \& Ngien, 2020; Noon, 2020; Yang, 2016).

Erikson explained that in early adolescence, identity vs identity confusion occurs, the transition of children to adults, where individuals seek and build new identities. This stage is required to be passed to avoid uncertainty and discomfort about the role and future of late adolescence. Santrock (2005) suggests that the exploration carried out by adolescents in search of their identity continues until late adolescence. Adolescents try hard to be accepted and get positive values from the surrounding environment.

A good identity is built using Instagram to increase selfesteem. The underpinning theory of the study (Rosenberg et al., 1995) defines self-esteem as a person's positive or negative evaluation of himself as a whole. However, individuals often experience social comparison in accessing Instagram. Thus, individuals evaluate a person's opinion and ability by comparing themselves with others, or socalled social comparison (Myers, 2016). This leads individuals to look back on their progress, hinders explorations of identity, and reduces commitment (Noon, 2020).

This study supported the findings of a previous study (Hasanati \& Aviani, 2020) for the results of this study showing that there is a relationship between social comparison and self-esteem in Instagram users, where social comparisons correlated negatively and not significantly. This study is also following another study (Nabila Syachfira, 2020), since the correlation value was 0.241 and the p-value (Sig.) $=0.000<\alpha=0.01$. The results of this study indicate a low relationship between social comparison and self-esteem among students who were Instagram users. In line with a study conducted by Meidina 
(2016), the results of the study on the relationship between social comparison and self-esteem showed a negative and very low correlation. There was no social comparison difference in age differences. Meanwhile, self-esteem was not influenced by gender, age, and intensity.

Additional data explained that there was a significant correlation between social comparison to intensity. Furthermore, there was a gender difference, although not significant. Meanwhile, the relationship was not significant for age. This is supported by a study conducted by Meidina (2016) which explains that there is a significant correlation between social comparisons based on gender and intensity, but there is no difference based on age. The self-esteem variable also explains that there is no significant correlation with gender, age, and duration. This study is supported by a previous study (Hasanati \& Aviani, 2020) which found that there were no differences in self-esteem based on gender, age, and intensity.

\section{CONCLUSIONS AND SUGGESTIONS}

Based on the results, it can be concluded that there is a weak, negative correlation between social comparison and self-esteem in late adolescence. It was found that there is a correlation between social comparison and the dimensions of self-esteem. Meanwhile, there is also correlation between self-esteem and social comparison dimensions. The researchers hope that the findings will be useful for the development of Psychology, especially in Social Psychology, Clinical Psychology, and Developmental Psychology. This study can also be used as a preliminary and evaluation material for other researchers who wish to know the relationship between social comparison and selfesteem. Researchers also contributed empirical data regarding the relationship between social comparison and self-esteem in late adolescents who use Instagram. This research is expected to be especially useful for adolescents, parents, schools, and other social environments. Researcher's suggestion for adolescents is to limit themselves to using social media so that they do not limit their views and standards based on social media. A positive mindset is the main key to self-confidence, and not comparing oneself with others because each individual has their own strengths and weaknesses. The role of adults cannot be separated from how adolescents see themselves and others. Parents have the role of teaching kindness and exemplary attitudes with correct parenting, supporting children's hobbies, and making their children feel valued. this can increase self-confidence and reduce negative views of oneself and others. The role of the school is to provide a platform to discover one's abilities, provide useful lessons and socialize with peers, and teachers need to behave fairly towards all students. Teenagers often have a certain circle of friends, and it is necessary to choose a positive environment that is mutually respectful and mutually supportive.

\section{ACKNOWLEDGMENT}

Reseacher would like to thank to Tarumanagara University for the opportunity, every participant who was participate and contribute in this research.

\section{REFERENCES}

[1] Napoleon. (2020). Instagram users in Indonesia : August 2020. https://napoleoncat.com/stats/instagram-users-inindonesia/2020/08

[2] Santrock, J. W. (2014). ADOLESCENCE (Fifteenth). McGraw-Hill Education.

[3] Jiang, S., \& Ngien, A. (2020). The Effects of Instagram Use, Social Comparison, and Self-Esteem on Social Anxiety: A Survey Study in Singapore. Social Media and Society, 6(2). https://doi.org/10.1177/2056305120912488

[4] Erikson, E. (1987). Childhood and Society. PALADIN GRAFTON BOOKS. file:///C:/Users/t00154854/ Downloads/[Erik_H._Erikson]_Childhood_and_Society(B ookZZ.org).pdf

[5] Santrock, J. W. (2005). Adolescence (10th ed.). McGraw-Hill Education.

[6] World Health Organization (WHO). (2010). Stages of Adolescent Development. World Health Organization (WHO). https://apps.who.int/adolescent/second-decade/ section/section_2/level2_2.php

[7] Rosenberg, M., Schooler, C., Schoenbach, C., \& Rosenberg, F. (1995). Global Self-Esteem and Specific Self-Esteem: Different Concepts, Different Outcomes. American Sociological Review, 60(1), 141. https://doi.org/ $10.2307 / 2096350$

[8] Myers, D. G. (2016). Social Psychology (J. M. Twenge (ed.); twelfth). McGraw-Hill Education.

[9] Schwartz, S. J., Luyckx, K., \& Editors, V. L. V. (2011). Handbook of Identity Theory and Research (Vol 1). Springer.

[10] Golbeck, J. J. (2015). Introduction to Social Media Investigation: A Hands-on Approach (J. L. Klavans (ed.)). Elsevier, Waltham, MA.

[11] Chua, T. H. H., \& Chang, L. (2016). Follow me and like my beautiful selfies: Singapore teenage girls' engagement in self-presentation and peer comparison on social media. Computers in Human Behavior, 55(February 2016), 190-197. https://doi.org/10.1016/j.chb.2015.09.011 
[12] Amelia, G. A. (2019). Pengaruh Social Comparison Terhadap Life Statisfaction Pada Remaja Akhir Yang Menggunakan Instagram. shorturl.at/kpzBI

[13] Gabriela Martorell, Diane E. Papalia, R. D. F. (2014). A Child's World in the City: Infancy Through Adolescence (13th ed.). McGraw-Hill Education.

[14] Corey, G. (2017). Theory and Practice of Counseling and Psychotherapy (10th ed.). Cengage Learning.

[15] Gruzd, A., Jacobson, J., Wellman, B., \& Mai, P. H. (2017). Social Media and Society: Introduction to the Special Issue. American Behavioral Scientist, 61(7), 647652. https://doi.org/10.1177/0002764217717567

[16] Noon, E. J. (2020). Compare and despair or compare and explore? Instagram social comparisons of ability and opinion predict adolescent identity development. Cyberpsychology, 14(2). https://doi.org/10.5817/CP2020$2-1$

[17] Rosenberg, M. (1965). Society and the Adolescent Self-Image. Princeton University Press.

[18] Mruk, C. J. (1995). Self-esteem: research, theory, and practice. In Choice Reviews Online (Vol. 32, Issue 10). https://doi.org/10.5860/choice.32-5938 